\title{
Physicochemical stability of lycopene-loaded emulsions stabilized by plant or dairy proteins
}

Food Structure (accepted manuscript)

DOI: https://doi.org/10.1016/j.foostr.2016.12.001

Kacie K.H.Y. Ho ${ }^{\mathrm{ab}}$, Karin Schroën ${ }^{\mathrm{a}}$, M. Fernanda San Martín-González ${ }^{\mathrm{c}}$, Claire C.BertonCarabin $^{\text {a* }}$

${ }^{a}$ Food Process Engineering Group, Department of Agrotechnology and Food Sciences, Wageningen University, Bornse Weilanden 9, 6708 WG, Wageningen, The Netherlands

bPlants for Human Health Institute, Department of Food, Bioprocessing and Nutrition Sciences, North Carolina State University, Kannapolis, NC, 28081, USA

'Department of Food Science, College of Agriculture, Purdue University, 745 Agriculture Mall Drive, West Lafayette, IN, 47907, USA

*Corresponding Author

Keywords: Emulsions, Plant proteins, Dairy proteins, Lycopene encapsulation, Physicochemical stability, Interfacial rheology

\section{Highlights}

- Lycopene-loaded emulsions were prepared with plant or dairy protein emulsifiers.

- Caseinate and pea protein-stabilized emulsions were physically stable for 14 days.

- After 14 days of incubation $>65 \%$ of the lycopene remained encapsulated.

- Pea protein is an interesting alternative for dairy protein in emulsion production. 


\begin{abstract}
Lycopene is a lipophilic bioactive compound that can be challenging to deliver in vivo. To mediate this, delivery strategies, such as protein-stabilized oil-in-water $(\mathrm{O} / \mathrm{W})$ emulsions, have been suggested to improve the physicochemical stability and bioavailability of lycopene. In this research, the effects of plant (soy and pea) and dairy (whey and sodium caseinate) proteins on physical stability (droplet size, charge, interfacial rheology) and lycopene retention in canola $\mathrm{O} / \mathrm{W}$ emulsions $(\mathrm{pH}=7.0,10 \%$ oil $)$ were compared.

Particle size distribution for sodium caseinate and pea protein-stabilized emulsions remained unchanged after 14 days of refrigerated storage, while whey and soy protein isolate-stabilized emulsions became unstable. Zeta potential was largely negative $(-45$ to $-60 \mathrm{mV})$ for all emulsions and the lycopene concentration in plant protein-stabilized emulsions at 14 days of storage was similar to that in sodium caseinate-stabilized emulsions. Sodium caseinate formed relatively viscous films at the oil-water interface, while the other proteins formed more elastic layers. Despite this difference, both the caseinate and pea protein-stabilized emulsions were promising delivery vehicles, indicating that plant-derived proteins can be feasible alternatives to dairy emulsifiers.
\end{abstract}

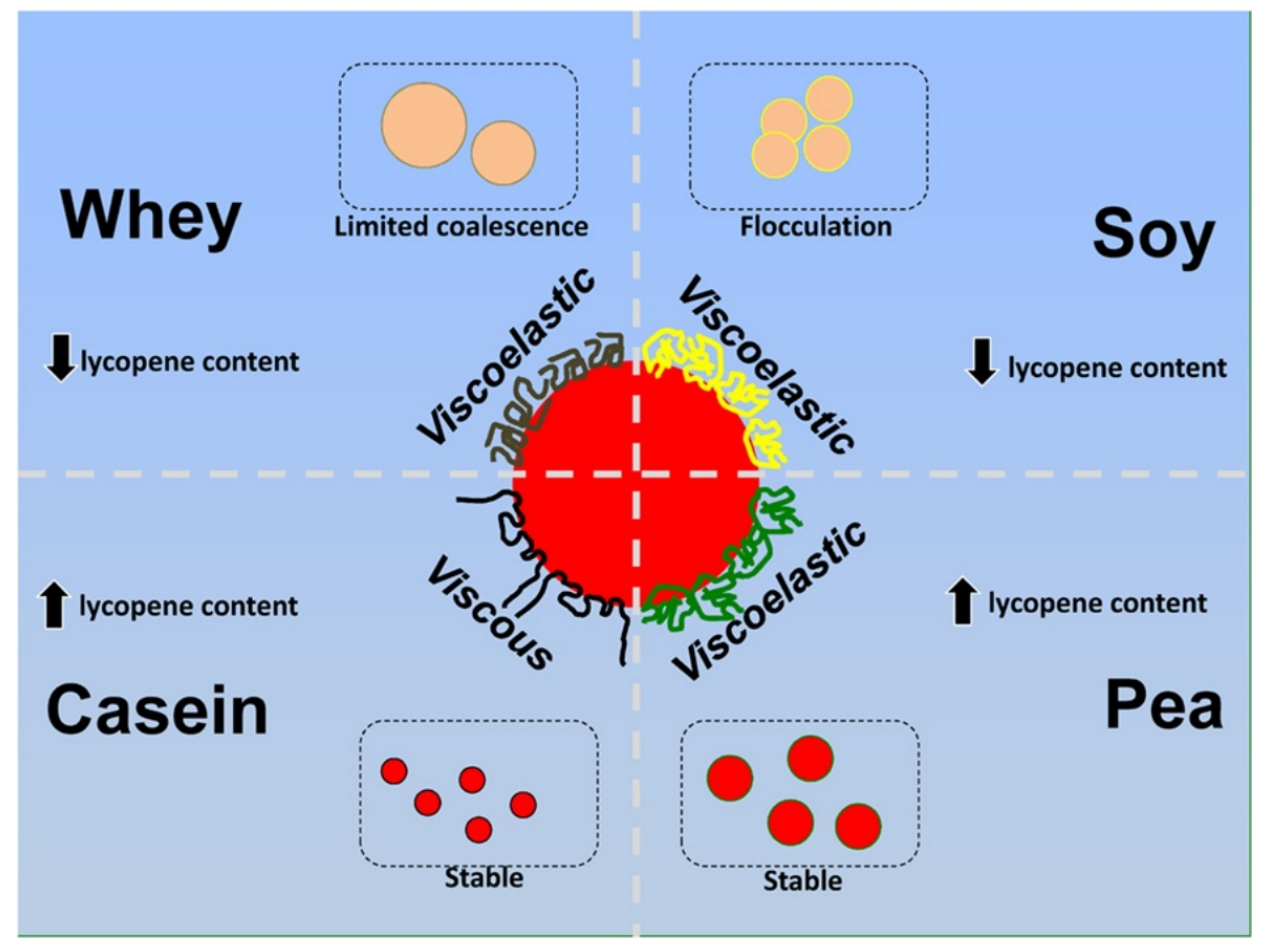


Food Structure

Volume 12, 2017, Pages 34-42

\section{Introduction}

Recently, there has been growing interest in enriching food products with bioactive ingredients (e.g., flavors, vitamins, antioxidants or phytochemicals) to produce a desired functionality. Lycopene is the most potent singlet oxygen quencher amongst carotenoids (Di Mascio, Kaiser, \& Sies, 1989; Rao, Waseem, \& Agarwal, 1998) that could be used as a naturally derived antioxidant or as a health-promoting ingredient. However, lycopene is largely insoluble in water and chemically labile. Therefore, encapsulation strategies should be considered, such as using emulsion-based delivery systems.

Dairy proteins have been extensively used for food applications, and in particular to stabilize the interface in oil-in-water $(\mathrm{O} / \mathrm{W})$ emulsions. Compared to other emulsifiers (e.g., surfactants or modified starch), dairy proteins, such as whey protein isolate (WPI) and sodium caseinate (SC), can improve the physical and chemical stability of carotenoid-loaded emulsions (Mao et al., 2009; Mao, Yang, Yuan, \& Gao, 2010). The high colloidal stability is attributed to the ability of dairy proteins to form thick and sterically-stabilized interfacial layers (Dickinson, 2001). In emulsion stability, the interfacial protein layer plays a critical role in the physical stabilization process (Wilde, 2000). Amongst dairy proteins, whey proteins (mostly represented by the globular protein $\beta$-lactoglobulin) have a rigid structure, which is known to lead to different interfacial organization compared to SC (primarily $\beta$-casein), which has a flexible structure (Dickinson, 2013) and in turn may lead to different effects on the physical and perhaps chemical stability of emulsions. Besides, Cornacchia and Roos (2011) found that the different protein chemistries of WPI and SC affected $\beta$-carotene retention in $\mathrm{O} / \mathrm{W}$ emulsions, with the latter protein providing a better oxidative barrier. Dairy protein emulsifiers have also proved to promote the bioavailability of bioactives. Ribeiro et al. (2006) found that interfacial WPI combined with Tween 20 or sucrose laurate improved cellular uptake of lycopene and astaxanthin, compared to emulsions stabilized with only Tween 20 in colon carcinoma cells (lines HT-29 and Caco-2). Although the mechanism of enhanced bioavailability was not elucidated, the authors alluded to potential interactions between the carotenoids and $\beta$ lactoglobulin as a possible explanation.

The drawback of using dairy proteins for producing functional food emulsions is their low sustainability and impact on the environment (Erb et al., 2016, VandeHaar and St-Pierre, 2006). Plant proteins represent a large and relatively underutilized resource that is more sustainable and requires less energy for production compared to their animal-derived counterpart (de Boer, Helms, \& Aiking, 2006; O’Kane, Vereijken, Happe, Gruppen, \& J S Van Boekel, 2004). Recent reviews (Shi \& Dumont, 2014; Song, Tang, Wang, \& Wang, 2011) have also highlighted functional properties of different biobased films from plant proteins as the utilization of such renewable proteins has gained popularity. Despite the growing interest for plant-derived proteins as emulsifiers (Chihi, Mession, Sok, \& Saurel, 2016), the link with stabilization of bioactive components in $\mathrm{O} / \mathrm{W}$ delivery systems is hardly ever made. Many plant proteins, including soy protein isolate (SPI) and pea protein isolate (PPI) have been reported as promising functional emulsifiers (Aoki, Taneyama, \& Inami, 1980; Bengoechea, Cordobés, \& Guerrero, 2006; Lam \& Nickerson, 2013; Pelgrom, Berghout, Van Der Goot, Boom, \& Schutyser, 2014; Phoon, San Martin-Gonzalez, \& Narsimhan, 2014), yet it is still arguable whether they perform as well as dairy proteins, or even outperform them (Chove, Grandison, \& Lewis, 2001). SPI and PPI are 
both from commonly consumed plant sources and exhibit good emulsifying properties as they have been shown to form stable $\mathrm{O} / \mathrm{W}$ droplets that were not drastically bigger compared to $\beta$ lactoglobulin-stabilized droplets (Benjamin, Silcock, Beauchamp, Buettner, \& Everett, 2014). Interfacial properties of SPI and PPI have also been studied and demonstrate potential to physically stabilize $\mathrm{O} / \mathrm{W}$ emulsions by forming strong viscoelastic films (Chang et al., 2015). Despite the numerous studies characterizing soy and pea protein functionality, limited work (Fernandez-Avila, Arranz, Guri, Trujillo, \& Corredig, 2016; Tapal \& Tiku, 2012) has been conducted specifically on SPI, consisting primarily of globular proteins glycinin and conglycinin (Chronakis, 1996), and PPI, consisting primarily of legumin and vicilin/convicilin (O'Kane et al., 2004), for improving bioactive delivery. Tapal and Tiku (2012) conducted research on curcumin and SPI complexation and found that $>80 \%$ of the bioactive was retained during simulated gastric conditions. Fernandez-Avila et al. (2016) also found promising results for plant protein (SPI and PPI)-stabilized emulsions, as conjugated linoleic acid (CLA) delivery was enhanced compared against non-emulsified CLA for both proteins in a Caco-2 cell model. Despite these promising first results, it is still unknown whether plant proteins could be a valuable alternative to dairy proteins for the production of functional emulsions loaded with bioactives, such as lycopene. In fact, direct comparisons between plant and dairy proteins and the link between interfacial properties and bioactive encapsulation have hardly been touched upon.

For the design of emulsion-based encapsulation systems, we believe it is necessary to connect the physicochemical stability of emulsions with the structural organization of the oil-water interface. Consequently, the aims of this study were to determine the effect of interfacial dairy or plant protein on the: 1) physical stability (particle size and zeta potential) and 2) chemical stability (lycopene retention) of emulsions, and 3) interfacial organization (adsorption kinetics and dilatational rheology). Ultimately, we have attempted to relate these findings and provide guidelines for the design of sustainable protein-stabilized emulsion-based delivery systems.

2. Materials and methods

2.1. Materials

Canola oil and tomato paste for lycopene extraction were purchased from local supermarkets (Wageningen, Netherlands). MP Alumina N-Super I (MP Biomedicals, France) was mixed with canola oil overnight as previously described (Berton, Genot, \& Ropers, 2011) to strip the oil of tocopherols and surface-active impurities. All-trans-lycopene standard, all solvents (analytical grade) and other reagents were purchased from Sigma Aldrich (Zwijndrecht, the Netherlands). Proteins were generously donated by the suppliers as follows: $97.5 \%$ purity WPI (BIPRO, Davisco, Switzerland), $80 \%$ purity SC (Sodium Caseinate S, DMV International, Amersfoort, Netherlands), and $90 \%$ purity SPI (soy protein isolate SUPRO EX 37, Solae Europe SA, Switzerland) and 80-90\% PPI (pea protein isolate NUTRALYS F85, Roquette, France). Ultrapure water (Millipore Milli-Q water purification system) was used for all experiments.

\subsection{Methods}

\subsubsection{Preparation of lycopene oil stock}

Approximately $250 \mathrm{~g}$ of tomato paste were combined with $10 \mathrm{~g}$ of celite, $10 \mathrm{~g}$ of sodium bicarbonate, and $500 \mathrm{~mL}$ of an extraction solvent $(1: 1 \mathrm{v} / \mathrm{v}$ hexane $(0.1 \%$ butylated 
hydroxytoluene w/v) - ethyl acetate). The mixture was held under a stream of nitrogen and in an ice-bath while stirring at $250 \mathrm{rpm}$ with an overhead IKA mixer for 1.5 hours. The mixture was then vacuum filtered with No. 1 filter paper (Whatman, United Kingdom) to separate solids from liquids, transferred to a separatory funnel, and washed with a saturated solution of sodium chloride in water. The lower aqueous phase was drained and the upper hexane layer was collected, flushed with nitrogen and rotary evaporated almost to dryness. Stripped oil ( $\sim 80 \mathrm{~g})$ was added to solubilize the lycopene crystals prior to transferring to a borosilicate screw top bottle. The resulting lycopene-in-oil mixture was held under a stream of nitrogen to remove residual solvent until constant weight was achieved. This entire process was repeated 10 times and individual batches of lycopene oil were pooled, prior to aliquoting into $35 \mathrm{~mL}$ batches, flushing with nitrogen, and storing at $-20^{\circ} \mathrm{C}$. The lycopene content of the stock oil was determined after dilution in hexane spectrophotometrically at $471 \mathrm{~nm}$, analyzed using highperformance liquid chromatography (Kean, Hamaker, \& Ferruzzi, 2008), and then compared against an all-trans-lycopene standard to identify cis- and trans- isomers (Ho, Ferruzzi, Liceaga, \& San Martín-González, 2015). The resulting stock oil had a total lycopene concentration of $0.236 \mathrm{mg} / \mathrm{g}$ of oil and consisted primarily of all-trans-lycopene ( 90\%).

\subsubsection{Preparation of the aqueous phase}

WPI and SC were added to $0.01 \mathrm{M}$ phosphate buffer $(\mathrm{pH}=7)$ and stirred with a magnetic stir bar overnight at room temperature at $100 \mathrm{rpm}$ prior to emulsification the following morning. Preliminary experiments showed SPI and PPI contained an insoluble fraction (Supplementary data, Table A.1), which negatively affected the emulsifying properties. Hence, the nonsoluble fraction of the plant protein was removed prior to emulsification. SPI or PPI were combined with $0.01 \mathrm{M}$ phosphate buffer $(\mathrm{pH}=7)$ and stirred for $48 \mathrm{~h}$ at $200 \mathrm{rpm}$ at $4^{\circ} \mathrm{C}$. The resulting mixtures were centrifuged at $10,000 \times \mathrm{g}$ for $10 \mathrm{~min}$ at $20^{\circ} \mathrm{C}$. The supernatant was collected and centrifuged again under the same conditions. The resulting supernatant, containing the soluble protein fraction, was carefully collected and stored at $4^{\circ} \mathrm{C}$ prior to use. The soluble protein concentration was estimated following a standard protocol for BCA Protein Assay (Thermoscientific, 2015). The removed pellet, $\sim 70 \mathrm{wt} \%$ (SPI) and $\sim 75 \mathrm{wt} \%$ (PPI) of the protein isolate mass, likely contained insoluble proteins and polysaccharides. The day prior to emulsification, soluble plant protein solutions were diluted with $0.01 \mathrm{M}$ phosphate buffer $(\mathrm{pH}=7)$ to obtain 5 or $7 \mathrm{~g} / \mathrm{L}$ of protein for SPI and PPI, respectively. The diluted solutions were stirred with a magnetic stir bar overnight at room temperature at $100 \mathrm{rpm}$ prior to emulsification the next morning.

\subsubsection{Preparation of lycopene-loaded emulsions}

Preliminary experiments were conducted to determine the optimal concentration of protein (WPI, SC, SPI, \& PPI) to use that would allow for small, physically stable emulsion droplets while limiting excess emulsifier using an adapted protocol from Berton, Genot et al. (2011). An excess protein amount $(<30 \%)$ was selected for all systems to obtain less than one-third of protein excess in the aqueous phase, while ensuring similar emulsion droplet sizes for all samples after emulsification. The aqueous phase of emulsions made with varying concentrations $(5-20 \mathrm{~g} / \mathrm{L})$ of protein was collected after centrifugation at $1840 \times \mathrm{g}$ for $1.5 \mathrm{~h}$. The amount of protein in the aqueous phase was then estimated as previously described (Thermoscientific, 2015) at $562 \mathrm{~nm}$ 


\section{Food Structure}

Volume 12, 2017, Pages 34-42

using a DU 720 UV-vis spectrophotometer (Beckman Coulter, Woerden, Netherlands). Selected concentrations of proteins for emulsions were determined to be $5 \mathrm{~g} / \mathrm{L}$ for WPI, SC, and SPI and $7 \mathrm{~g} / \mathrm{L}$ for PPI as these allowed for a small droplet size $(0.1-0.2 \mu \mathrm{m})$ while limiting the excess protein to $<30 \%$ of soluble protein (Supplementary data, Figure A.1).

Aliquots of lycopene stock oil were removed from freezer storage and placed in an ultrasonic water bath for $30 \mathrm{~min}$ to solubilize lycopene crystals in the oil. A coarse emulsion was prepared by mixing the lycopene oil stock $(10 \% \mathrm{wt})$ with aqueous protein solution $(90 \% \mathrm{wt})$ via an Ultra Turrax at $11,000 \mathrm{rpm}$ for $30 \mathrm{~s}$. The coarse emulsion was then immediately passed through a high pressure M-110Y Microfluidizer (Microfluidics, Massachusetts, USA) for five times at 800 bar. The freshly prepared emulsions were flushed with nitrogen and stored in borosilicate screw top vials at $4{ }^{\circ} \mathrm{C}$, in the dark. The resulting emulsions were sampled and measured (for physical stability) and aliquoted and stored (for chemical stability) at 0, 3, 7, and 14 days. Aliquots for lycopene quantification were stored in glass vials, covered with aluminium foil, flushed with nitrogen, and stored at $-20^{\circ} \mathrm{C}$ until tested.

\subsubsection{Physical stability of emulsions}

\subsubsection{Particle size}

Emulsion droplet size was measured using a static light scattering instrument (Mastersizer 2000, Malvern Instruments Ltd.; Worcestershire, UK). Non-diluted emulsion samples were directly added to an attached Hydro SM small volume sampling unit for measurement. In order to assess if samples flocculated, $1 \mathrm{~mL}$ of emulsion was added to $4 \mathrm{~mL}$ of $10 \%$ sodium dodecyl sulfate (SDS) solution in water, gently vortexed for a few seconds, and then the droplet size was measured again.

All samples were measured within an obscuration range of $12-16 \%$. Particle size of emulsion droplets is reported as the mean $\left(d_{3,2}\right)$ and represents the average of three independent emulsion measurements, each of which were the average of three measurements.

\subsubsection{Zeta potential}

The zeta potential of emulsions was determined by measuring the electrophoretic mobility of droplets via laser Doppler velocimetry using a Zetasizer Nano ZS (Malvern Instruments Ltd.; Worcestershire, UK). Measurements were conducted with a backscatter detection angle of $173^{\circ} \mathrm{C}$ and calculated following the Smoluchowski model with refractive indices of 1.330 and 1.475 for water and canola oil, respectively. Samples were diluted with ultrapure water to $1.25 \%$ (v/v) and measured after 2 min of equilibration at $25^{\circ} \mathrm{C}$ with 3 measurements per sample. The zeta potential values were expressed as the average from three independent samples.

\subsubsection{Chemical stability of emulsions}

2.2.5.1. Lycopene extraction and quantification in emulsions

Lycopene was extracted from emulsion samples using a method previously described (Ax, Mayer-Miebach, Link, Schuchmann, \& Schubert, 2003) with modifications. Precisely $3 \mathrm{~mL}$ of ethanol, $1 \mathrm{~mL}$ of saturated sodium chloride in water, and $4 \mathrm{~mL}$ of solvent $(0.1 \%$ BHT in hexane 


\section{Food Structure}

Volume 12, 2017, Pages 34-42

$\mathrm{w} / \mathrm{v}$ ) were added to $1 \mathrm{~mL}$ of emulsion sample. The samples were then vortexed and flushed with nitrogen prior to sonication for 5 min. Following this, a Pasteur pipette was used to carefully collect the upper hexane phase. Extraction with additional solvent was repeated until the hexane phase was colorless (4 repetitions). Extracts were diluted with hexane to achieve absorbance values between $0.1-0.8$, sonicated for $10 \mathrm{~s}$ to ensure solubilisation of lycopene crystals, and measured with a UV-vis spectrophotometer at $471 \mathrm{~nm}$. The total lycopene content was calculated using a molar extinction coefficient of $1.85 \times 10^{5} \mathrm{M}^{-1} \mathrm{~cm}^{-1}$, which was calculated as described previously (Britton, Liaaen-Jensen, \& Pfander, 2004). The chemical stability of lycopene was expressed as the relative retention of lycopene $\left(\mathrm{C}_{\text {relative }}\right)$ and the absolute lycopene content. The relative lycopene retention and the encapsulation efficiency (EE) are defined as follows (Eqs. (1) and (2)):

$$
\begin{gathered}
\text { (1) } C_{\text {relative }}(\%)=\left(\mathrm{C}_{t} / \mathrm{C}_{0}\right) \times 100 \\
(2) \mathrm{EE}=\left(\mathrm{C}_{0} / \mathrm{C}_{\mathrm{i}}\right) \times 100
\end{gathered}
$$

Where $C_{t}$ is the lycopene content (mg/100 $\mathrm{g}$ of emulsion) in the lycopene at time $\mathrm{t}$ and $C_{0}$ is the lycopene present in the emulsion on day 0 of storage. $C_{i}$ represents the amount of lycopene initially added to $100 \mathrm{~g}$ of emulsion. The absolute lycopene content was determined as the lycopene content (mg lycopene/100 g of emulsion) measured at each time point. Lycopene stability was determined in triplicate from three independent emulsions. To prevent lycopene degradation, all extractions were conducted in the dark. Hexane extracts containing lycopene were flushed with nitrogen, sealed in glass vials, wrapped in foil, and held on ice up until measurement (within $30 \mathrm{~min}$ ). Samples handled in this manner did not show differences in lycopene content when measured within this time frame.

\subsubsection{Properties of protein films at the oil-water interface}

\subsubsection{Adsorption kinetics}

The interfacial tension at the interface between stripped oil and aqueous protein solutions was measured using an automated drop tensiometer (Teclis, Longessaigne, France). Preliminary experiments (data not shown) indicated that there was no observable change in the adsorption kinetics of whey proteins when lycopene was present in the oil, compared to pure stripped oil (for a lycopene-to-whey protein ratio similar to that in emulsion systems). Therefore, stripped canola oil was used as the oil phase for this series of experiments. It was used to fill a $0.5 \mathrm{~mL}$ glass syringe, connected to a 16-gauge stainless steel needle to form a model oil droplet (surface area of $\left.60 \mathrm{~mm}^{2}\right)$. The continuous phase was protein solutions $(0.1 \mathrm{~g} / \mathrm{L})$ in $10 \mathrm{mM}$ phosphate buffer $(\mathrm{pH} \mathrm{7})$ in a $40 \times 23.6 \times 15 \mathrm{~mm}$ glass cuvette (Hellma Analytics, Jena, Germany). Protein adsorption kinetics was measured during 2-h runs to ensure equilibrium and was run in, at least, duplicate to ensure repeatability. Interfacial tension was determined by fitting the experimental data to the Young-Laplace equation. Following each experiment, needles and syringes were cleaned with a 1\% detergent solution (Hellmanex, Hellma Analytics, Jena, Germany) using an ultrasonic bath. Prior to use, needles and syringes were rinsed with ethanol and copious amounts of ultrapure water. 


\subsubsection{Interfacial rheology}

Following the 2-h equilibration period used to allow for protein adsorption at the oil-water interface, oscillation cycles were applied to the model drop to investigate the viscoelastic response of the protein interfacial film to dilatational deformation. The drop was subjected to amplitude sweeps $(2-35 \%)$ under a constant frequency of $0.01 \mathrm{~Hz}$. The dilatational elastic modulus $\left(E^{\prime} d\right)$ and the dilatational viscous modulus $\left(E^{\prime \prime} d\right)$ were determined from the intensity and phase of the first harmonic of a Fourier transform of the oscillating surface tension signal, and are defined as follows (Eqs. (3) and (4)):

$$
\begin{aligned}
& \text { (3) } E^{\prime}{ }_{d}=\Delta g\left(A_{0} / \Delta A\right) \cos \delta \\
& \text { (4) }{ }^{\prime}{ }_{d}=\Delta \gamma\left(A_{0} / \Delta A\right) \sin \delta
\end{aligned}
$$

Where $\Delta y$ is the change in surface tension, $A_{0}$ is the initial drop surface, $\Delta A$ is the change in drop surface during the oscillations and $\delta$ is the phase shift.

The loss tangent $(\tan \theta)$ was calculated by the following equation:

$$
\text { (5) } \tan \theta=\mathrm{E}{ }^{\prime \prime} / \mathrm{E}_{\mathrm{d}}
$$

\subsubsection{Statistical analysis}

All emulsions were prepared in triplicate with physical and chemical stability measurements reported as the mean and standard deviation of all measurements per emulsion type. Statistical analysis was conducted with JMP version 11 (SAS Institute Inc.; Cary NC, USA). Data were subjected to one-way analysis of variance (ANOVA) with $\alpha=0.05$. The Tukey-Kramer method was conducted post-hoc for mean comparisons $(\alpha=0.05)$.

3. Results and discussion

\subsection{Physical stability of lycopene-loaded emulsions}

All emulsions exhibited small droplet size $\left(\mathrm{d}_{3,2}: 0.13-0.29 \mu \mathrm{m}\right)$ between 0 and 14 days of storage (Fig. 1) with span values between 2.17-3.16 (Supplementary data, Figure A.2). At day 0, all emulsion droplet sizes had a $\mathrm{d}_{3,2}$ between 0.14 and $0.24 \mu \mathrm{m}$, yet plant protein-stabilized emulsion droplets were significantly larger compared to dairy-protein stabilized emulsions. SC-, WPI-, and PPI-stabilized emulsions remained physically stable with a similar droplet size at day 14 compared to day 0 (Fig. 2), in contrast to SPI-stabilized emulsions, which exhibited a larger $\mathrm{d}_{3,2}$ value at day 14. In order to understand what caused this, all emulsion samples were measured with and without SDS to check for flocculation. The SC and PPI-stabilized emulsions exhibited similar particle size distributions at day 0 and day 14, with and without SDS (Fig. 2), indicating they were not subjected to flocculation. Conversely, the SPI-stabilized emulsion showed particle size distributions that exhibited a left-shift when diluted in SDS solution, both at $\mathrm{t}=0$ and 14 days indicating that some flocculation occurred. Yet, after addition of SDS the particle size distribution of SPI-stabilized emulsions was similar at day 0 and day 14, indicating that the emulsion was stable to coalescence. The particle size distribution of the WPI-stabilized emulsion 
shifted to higher values after 14 days compared to the initial measurement, which remained unchanged after SDS treatment, indicating that coalescence occurred to a limited extent.

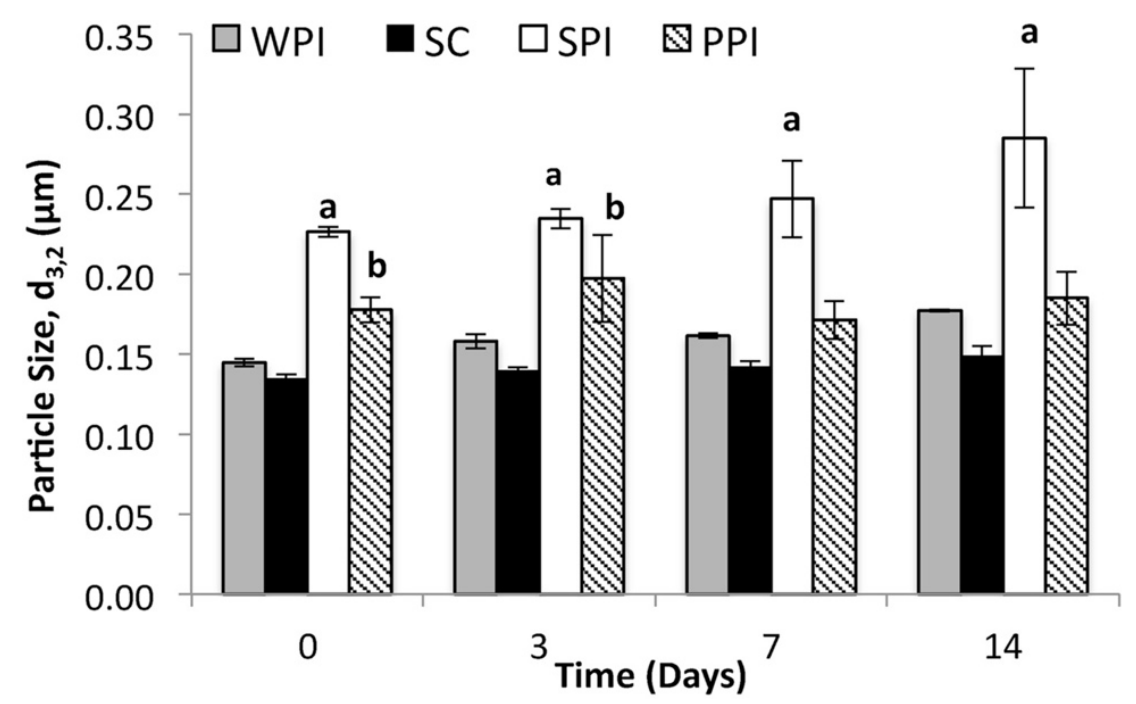

Fig. 1. Particle size ( $\mathrm{d}_{3,2}$; left y-axis) of lycopene-loaded emulsions over time. Response values shown represent the mean \pm standard deviation $(\mathrm{n}=3)$, with letters denoting samples that are significantly different at a given storage time $(\alpha=0.05)$.
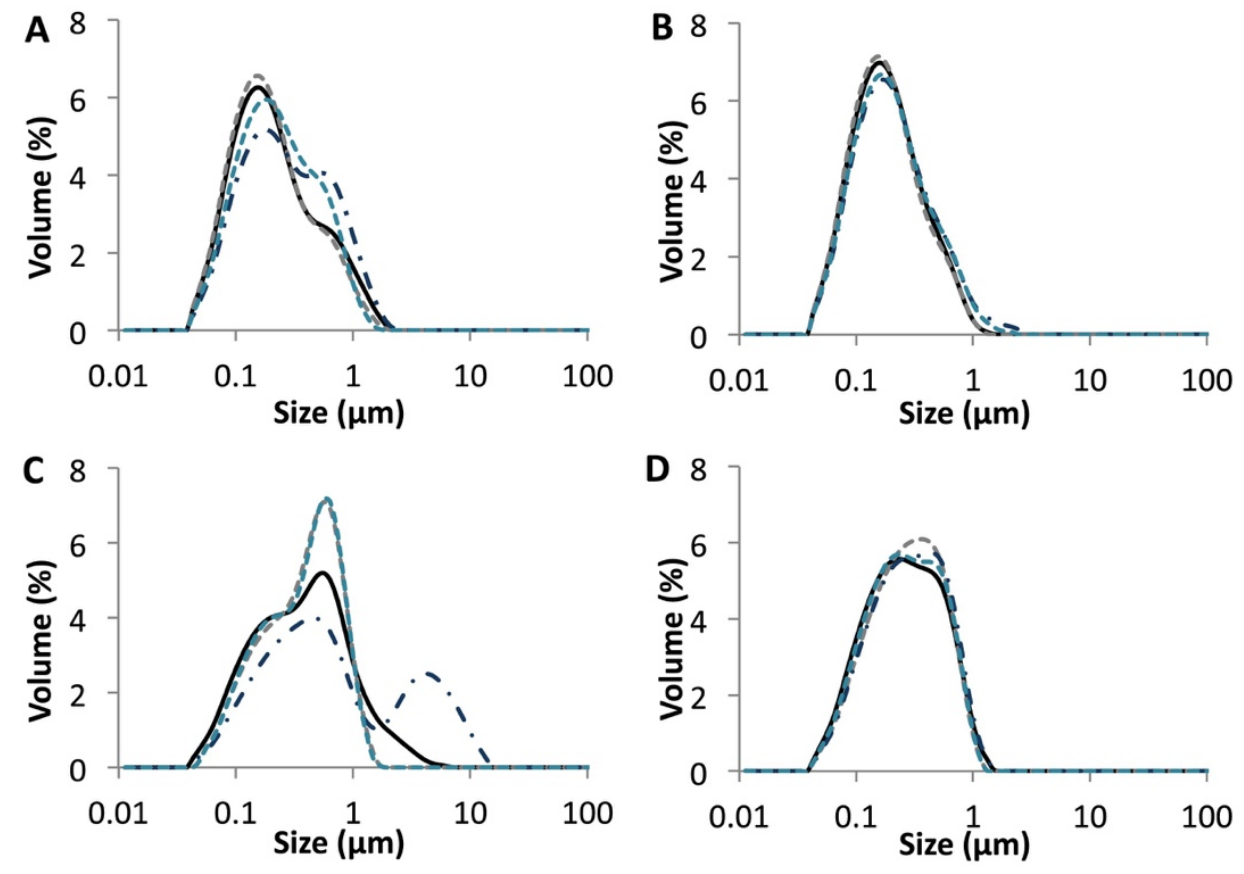

Fig. 2. Comparison of particle size distributions of lycopene-loaded emulsions stabilized with WPI (A), SC (B), SPI (C), and PPI (D) at day 0 (solid line, black), day 0 with $1 \%$ SDS (solid line, gray), day 14 (dotted line, black), and day 14 with 1\% SDS (dotted line, blue). Identical distributions with and without SDS dilution suggest that flocculation did not occur in such samples. When Day 0 and Day 14 distributions are identical the emulsions are stable. 
All samples exhibited negative initial zeta potentials between -45 and $-60 \mathrm{mV}$, which did not change over the course of 14 days (Supplementary data, Fig. A.3). Large negative zeta potential values were expected as emulsions were prepared at a $\mathrm{pH}$ above the isoelectric point of all proteins tested (Supplementary data, Table A.1). Although zeta potential can give an indication of electrostatic stabilization, proteins are mostly known for the formation of thick, viscoelastic layers at the oil-water interface that are directly linked to their efficiency at preventing emulsion droplet coalescence (Dickinson, Owusu, Tan, \& Williams, 1993), as will be discussed in more detail in the interfacial rheology section.

\subsection{Encapsulation stability of lycopene-loaded emulsions}

All emulsions contained around $1.4 \mathrm{mg}$ lycopene $/ 100 \mathrm{~g}$ emulsion directly after their preparation, and by the end of storage after 14 days they all had a relative lycopene retention $>65 \%$ (Fig. 3) corresponding to $>0.8 \mathrm{mg} / 100 \mathrm{~g}$ emulsion. The highest relative lycopene retention amongst emulsions was with SC at $\sim 87 \%$, closely followed by PPI, with a retention of $\sim 81 \%$. Both values were significantly higher than found for the WPI- and SPI-stabilized emulsions. Although the lycopene stabilities were statistically different depending on the chosen protein, we should consider that differences in droplet surface area could also have affected the physicochemical stability. SC has been reported to better protect emulsions against lipid oxidation compared to WPI, and also better than SPI (Hu, McClements, \& Decker, 2003), which is in accordance with our findings. The relatively low stability obtained with WPI compared to the work of Hu may be the result of the difference in $\mathrm{pH}$ that was applied, 3.0 versus 7.0 used for this study: isoelectric points are $\sim 5.1$ for WPI (Alting, Hamer, de Kruif, \& Visschers, 2000) and $~ 5.6$ for SPI and PPI (Chove et al., 2001; Liu, Elmer, Low, \& Nickerson, 2010). Antioxidant properties of the legume proteins may have also influenced the lycopene stability of the PPI and SPI-stabilized emulsions. Han and Baik (2008) reported that both the free (soluble) and bound (insoluble) portion of soy and peas exhibit antioxidant activity. 
Food Structure

Volume 12, 2017, Pages 34-42

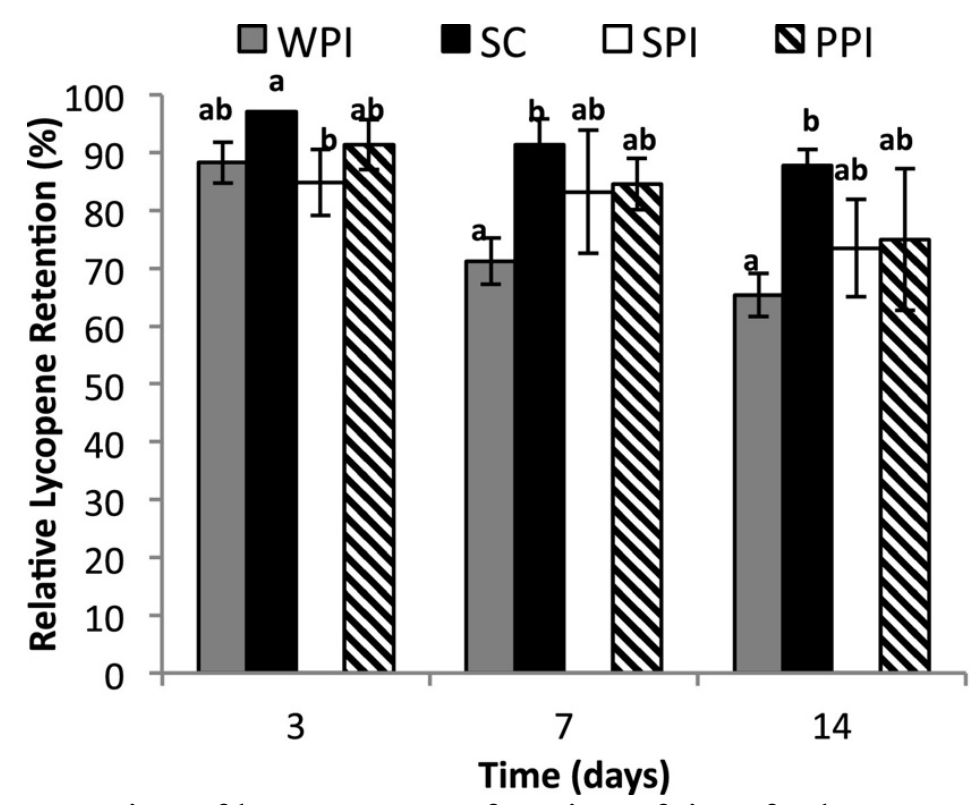

Fig. 3. Relative retention of lycopene, as a function of time for lycopene-loaded emulsions. Response values shown represent the mean \pm standard deviation $(n=3)$, with same letters denoting values that are not significantly different $(\alpha=0.05)$.

3.3. Properties of protein layers at the oil-water interface

\subsubsection{Adsorption kinetics}

Interfacial tension at the oil-water interface with proteins initially dissolved in the aqueous phase was determined and expressed as a function of time (log scale) as shown in Fig. 4. In the absence of protein, the stripped oil-water interface exhibited a constant interfacial tension at $\sim 36 \mathrm{mN} / \mathrm{m}$ (data not shown) and was in accordance with values previously obtained in our laboratory for stripped vegetable oil, whereas a decrease in interfacial tension over time was observed when proteins were present. SC, SPI, and PPI led to roughly similar equilibrium interfacial tensions of approximately $15.8 \mathrm{mN} / \mathrm{m}, 15.6 \mathrm{mN} / \mathrm{m}$, and $15.9 \mathrm{mN} / \mathrm{m}$, respectively, by the end of the two hour run while WPI led to a higher value at roughly $18.3 \mathrm{mN} / \mathrm{m}$, indicating that it is less surface active in comparison to the other proteins. 
Food Structure

Volume 12, 2017, Pages 34-42

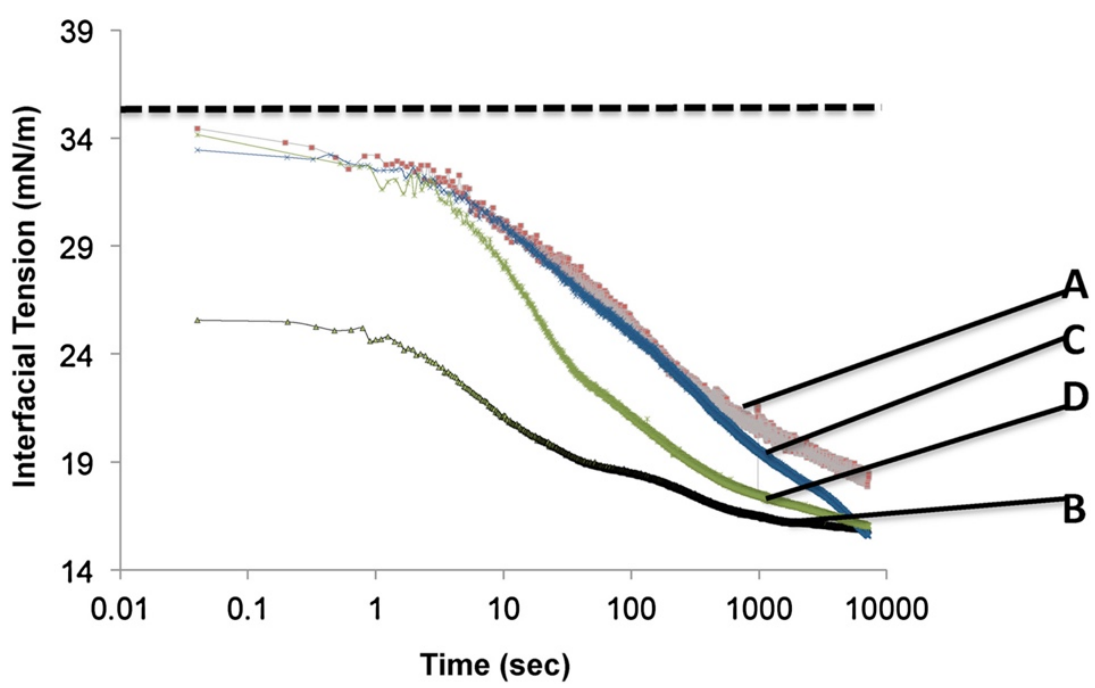

Fig. 4. Adsorption kinetics of WPI (A), SC (B), SPI (C), and PPI (D) at the O/W interface as a function of time (log scale). The slope of the line correlates with the rate of adsorption to the interface. The dashed line represents the interfacial tension of the stripped oil-water interface in the absence of protein at $\sim 36 \mathrm{mN} / \mathrm{m}$.

SC appeared to have the fastest rate of adsorption, followed by the plant proteins-PPI being faster than SPI-with WPI exhibiting the slowest rate of adsorption at the oil-water interface. SC adsorbs quickly to the interface due to a relatively higher amount of nonpolar groups compared to proteins such as WPI (Dickinson, 2011, Nakai and Li-Chan, 1988). SC differs from WPI, SPI, and PPI in its structure; specifically $\beta$-casein consists of flexible, random coil proteins with little secondary structure due to the number and distribution of prolyl residues, and to a lack of covalent intramolecular bonding (Dickinson, 2001), which makes caseins flexible, amphiphilic proteins. Conversely, disulfide bridges and cysteine residues in $\beta$-lactoglobulin, the main component of WPI, stabilize the protein's globular tertiary structure (McClements, Monahan, \& Kinsella, 1993). WPI may show the slowest rate of adsorption because of its rigidity and relatively slow conformational changes at the interface compared to SC. In particular, the random coil structure of SC allows for rapid conformational changes at the interface, and therefore faster decrease in the interfacial tension (Freer et al., 2004), whereas WPI and the globular plant proteins (SPI and PPI) have stronger intra-protein interactions that limit the rate of adsorption at the oil-water interface. Although the adsorption kinetics provide insights into potential interfacial behaviour of the different proteins, it does not predict emulsion stability. Besides, protein flexibility affects the structure of the formed interfacial films, which is investigated in more detail in the next section.

\subsubsection{Interfacial rheology}

In emulsions, coalescence can happen if a hole is created in the interfacial film that separates two colliding droplets. Such a rupture can be seen as a dilatational deformation, thus we tested the dilatational properties of protein-stabilized interfaces (Bos and van Vliet, 2001, Murray, 2011). With the exception of WPI, the elastic and viscous moduli of the protein layers did not have a 
large dependence on the applied deformation (Fig. 5), implying that the measurements were conducted within the linear viscoelastic regime. Compared to all other samples, the SC layer exhibited substantially lower elastic moduli (Fig. 5A), and thus higher loss tangent (Fig. 5B), while the elastic moduli for WPI, SPI, and PPI all appear to be substantially higher $(>15 \mathrm{mN} / \mathrm{m})$ than their corresponding loss moduli. This indicates that the SC layer exhibited more viscous behaviour compared to the other protein layers, which is likely due to the random coil and lack of secondary structure characteristic of SC (Dickinson, 1992). Our findings are in agreement with other studies in which SC was also reported to form viscous layers at the oil-water interface (Erni, Windhab, \& Fischer, 2011) due to loose packing and weak interactions between interfacial casein proteins (Dickinson, 2001). A viscous interface, which is characteristically less dense and compact compared to an elastic one, is formed with SC primarily due to its flexibility as a protein, but also due to its hydrophobicity as SC preferentially orients along the oil phase as opposed to building adsorbed layers at the oil-water interface (Maldonado-Valderrama et al., 2005).
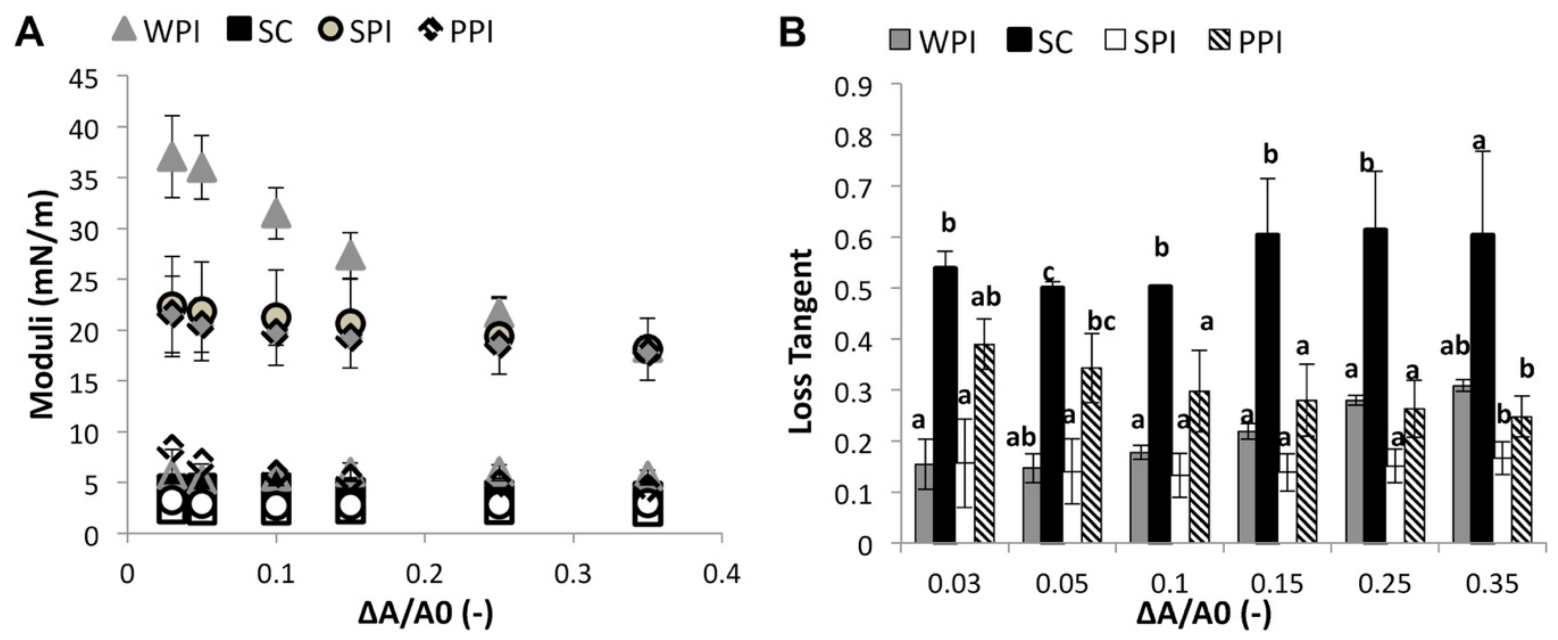

Fig. 5. Elastic (filled shapes) and loss (open shapes) moduli (A) and loss tangent (B) of proteins at deformations between 0.03 and 0.35 . Higher loss tangent values indicate a more viscous response, while lower values indicate a more elastic behavior. Response values shown represent the mean \pm standard deviation $(n=3)$. Statistical differences amongst protein films are shown (B) with same letters denoting values that are not significantly different $(\alpha=0.05)$.

Compared to SC-based interfaces, WPI-based ones exhibited a more elastic behaviour, which can be attributed to strong intermolecular interactions and a high two-dimensional packing efficiency at the interface (Dickinson, 2001). SPI- and PPI-based layers exhibited loss tangents more similar to that of the WPI-based layer, which was expected since plant proteins are globular (Boye et al., 2010) and known to produce an interconnected, viscoelastic monolayer at the oilwater interface (Chang et al., 2015). 


\section{Food Structure}

\subsection{Comparison and design considerations for protein-stabilized emulsions}

All our emulsions had similar and small droplet size, therefore, effects of interfacial area, that are reported to potentially influence chemical stability (Lethuaut, Métro, \& Genot, 2002) or not (Berton-Carabin, Ropers, \& Genot, 2014; Hu, McClements, \& Decker, 2003; Osborn \& Akoh, 2004) can rather safely be disregarded in the interpretation of the results. Besides, we designed our emulsions in such a way that the fraction and concentration of non-adsorbed proteins was low, so that the contribution of this non-adsorbed fraction to their physicochemical stability was presumably limited (Berton, Genot et al., 2011, Berton, Ropers et al., 2011, Faraji et al., 2004).

Most probably, the protein properties and the resulting interfacial layers affect lycopene stability. Steric forces influence emulsion physical stability, particularly for SC-stabilized emulsions, as electrostatic forces are expected to play a lesser role in stabilization for flexible proteins (Dickinson, 2010), while for the other less flexible proteins, thicker layers are expected to stabilize the interfaces. Hu et al., 2003a, Hu et al., 2003b discussed the amino acid composition of SC, which contains relatively high amounts of antioxidative tyrosine, proline, and methionine, as a potential explanation for improved oxidative stability of emulsions stabilized with SC compared to SPI and WPI, although they express that this relationship is not clear. In another study, high-pressure processing at 1379 bar vs. 345 bar was reported to induce a tighter packing in the cross-linked interfacial layer of SC-stabilized emulsions, which was related to a higher oxidative stability (Phoon, Paul, Burgner, Fernanda San Martin-Gonzalez, \& Narsimhan, 2014). Other studies have reported that increasing processing temperature of protein-stabilized emulsions results in further unfolding of proteins and potential alteration of conformation (Let, Jacobsen, Sørensen, \& Meyer, 2007). In particular, whey proteins have been reported to exhibit antioxidant properties post-homogenization due to the unfolding and exposure of sulfhydryl groups, which can either repel (Hu et al., 2003a) or scavenge free radicals (Let et al., 2007; Tong, Sasaki, Mcclements, \& Decker, 2000). Aside from the antioxidant effects of protein, other impurities (e.g., polysaccharides and starches) existing in the commercial plant protein isolates could contribute to the lycopene stability. In particular, phenolic compounds in peas, which exist primarily in the hulls (Shahidi et al., 2001), may have contributed to the chemical stability of the PPI-stabilized emulsions.

From the above it is clear that interfacial properties are related to the physicochemical stability of an emulsion, which is mostly linked to providing a denser barrier against oxidizing agents and coalescence (Georgieva, Schmitt, Leal-Calderon, \& Langevin, 2009), however it is difficult to find clear experimental evidence for this. As discussed previously, elastic interfaces are the result of an interconnected protein network. The gel-like viscoelastic interface observed in this study amongst WPI, SPI, and PPI-stabilized emulsions would be expected to form a rigid layer, which in theory could better physically stabilize the system and limit contact between the lipid phase and oxidizing agents. However, globular proteins may exhibit localized empty patches due to depletion (Bos \& van Vliet, 2001), which potentially has detrimental consequences for lycopene stability.

Despite the mechanical and structural properties of the interface, chemical properties, such as oxygen permeability through a protein layer, should also be taken into consideration. $\beta$-casein films at the air-water interface were found to have a higher oxygen permeability compared to 
that of $\beta$-lactoglobulin (Toikkanen et al., 2014), while $\beta$-casein-stabilized emulsions have been found to exhibit better oxidative stability (based on oxygen uptake and formation of conjugated dienes, hexane, and propanal) in various conditions compared to $\beta$-lactoglobulin-stabilized emulsions (Berton, Ropers, Bertrand, Viau, \& Genot, 2012; Berton, Ropers, Viau, \& Genot, 2011), and this is most probably caused by the fact that caseins are better at scavenging free radicals (Clausen, Skibsted, \& Stagsted, 2009) and binding iron (Faraji, Mcclements, \& Decker, 2004; Sugiarto, Ye, Taylor, Singh, \& Singh, 2010) compared to whey proteins.

Yet, protein flexibility and interfacial elasticity alone cannot be used to simply explain the stability of lycopene-loaded emulsions. It is likely that chemical properties of the proteins aided in lycopene stability, although future work could be done to directly assess this. Especially pea protein is of great interest; given its relatively high stability and encapsulation capacity, it is expected to serve as a genuine alternative for animal-based proteins in emulsion formulations.

\section{Conclusions}

This work systematically investigated the physical and chemical stability of lycopene-loaded emulsions prepared using various proteins as emulsifiers. Especially emulsions stabilized with casein and pea protein exhibited both high chemical (encapsulation\% $>80 \%$ ) and physical stability (no change in particle size) after 14 days. Interestingly, no correlation could be found between the elasticity of the protein layers at model oil-water interfaces, and the physicochemical stability of the corresponding emulsions. This is most probably due to the fact that adsorbed casein molecules induced strong steric repulsion, resulting in an additional emulsion stabilization effect, and lycopene protection effects due to the protein ability to chelate metals ions and scavenge free radicals.

Performance of each protein could be ranked for each property measured, however, it is perhaps more valuable to consider the collective characteristics for each of the protein-stabilized emulsions. Although SC appeared to perform optimally, PPI was a strong plant contender and demonstrated comparably good properties as it stabilized emulsions against flocculation and coalescence, exhibited relatively rapid protein adsorption, and stabilized lycopene to a similar extent as SC. Overall, SC and PPI both exhibited relatively good physical and chemical stabilization for lycopene-loaded emulsions, while SPI and WPI exhibited better stabilization for either physical or chemical stabilization, rather than both (Table 1). This research demonstrates that selected plant proteins can perform well compared to dairy proteins for lycopene encapsulation and have potential as dairy alternatives for chemical protection against oxidation in colloidal systems. 
Table 1. Summary comparison of physical and chemical properties lycopene-loaded emulsions stabilized with WPI, SC, SPI, or PPI. Proteins that strongly demonstrated relatively high $(++++)$ values for a given characteristic are compared against those with intermediate $(+++$ or ++$)$ and lower $(+)$ values.

\begin{tabular}{lllll}
\multicolumn{1}{r}{$\begin{array}{c}\text { Small Droplet } \\
\text { Size }\end{array}$} & \multicolumn{1}{c}{$\begin{array}{c}\text { Physical } \\
\text { Stability }\end{array}$} & \multicolumn{1}{c}{$\begin{array}{c}\text { Fast } \\
\text { Adsorption }\end{array}$} & \multicolumn{1}{c}{$\begin{array}{c}\text { Highly Elastic } \\
\text { Interface }\end{array}$} & $\begin{array}{l}\text { Lycopene } \\
\text { Retention }\end{array}$ \\
WPI ++ & ++ & + & ++++ & + \\
SC +++ & ++++ & ++++ & + & +++ \\
SPI + & + & ++ & ++++ & ++ \\
PPI ++ & +++ & +++ & ++ & +++
\end{tabular}

Industrial relevance text

This work investigated the physical and chemical stability of lycopene-loaded emulsions prepared with dairy or plant proteins as emulsifiers. The outcomes are highly relevant to industry, as they constitute a basis to formulate food emulsions that not only encapsulate highly lipophilic and labile bioactives, but that are also made of sustainable ingredients (plant proteins). This addresses the current priorities of the food sector, i.e., making foods that are both healthy and sustainable.

\section{Acknowledgements}

This research was based upon work supported by the National Science Foundation Graduate Research Fellowship (Grant No. DGE-1333468) through the Graduate Research Opportunities World Wide (GROW) program in support with the Netherlands Organisation for Scientific Research (NWO), and the Wageningen University Graduate School (VLAG). Laboratory work was conducted at Wageningen University in the Food Process Engineering Group. The authors would like to thank the laboratory technicians of the Food Process Engineering Group at Wageningen University, including Jos Sewalt, Martin de Wit, and Jarno Gieteling for assistance with experimental set up, and Maurice Strubel for his HPLC expertise. Marlies Geerts is also acknowledged for her help with the pea protein characterization. 


\section{Appendix A. Supplementary Data}

$\bullet-$ Particle Size $\rightarrow-$ Unadsorbed proteins
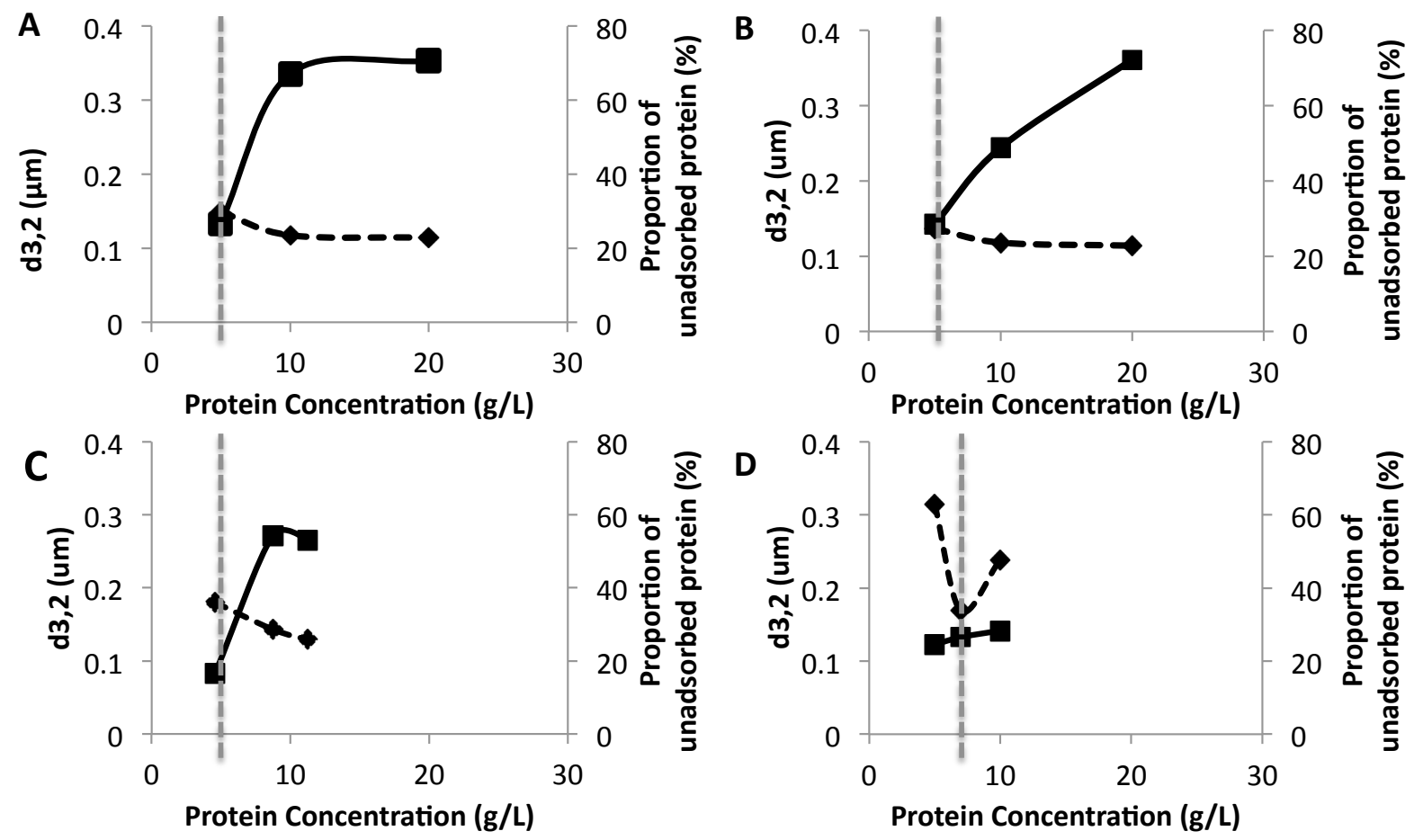

Figure A.1. Determination of optimal protein concentration. Particle size (left y-axis) and correlating percent of excess protein (right y-axis) versus protein concentration added tothe emulsion for WPI (A), SC (B), SPI (C), and PPI (D). Dashed line denotes the selected protein concentration. 


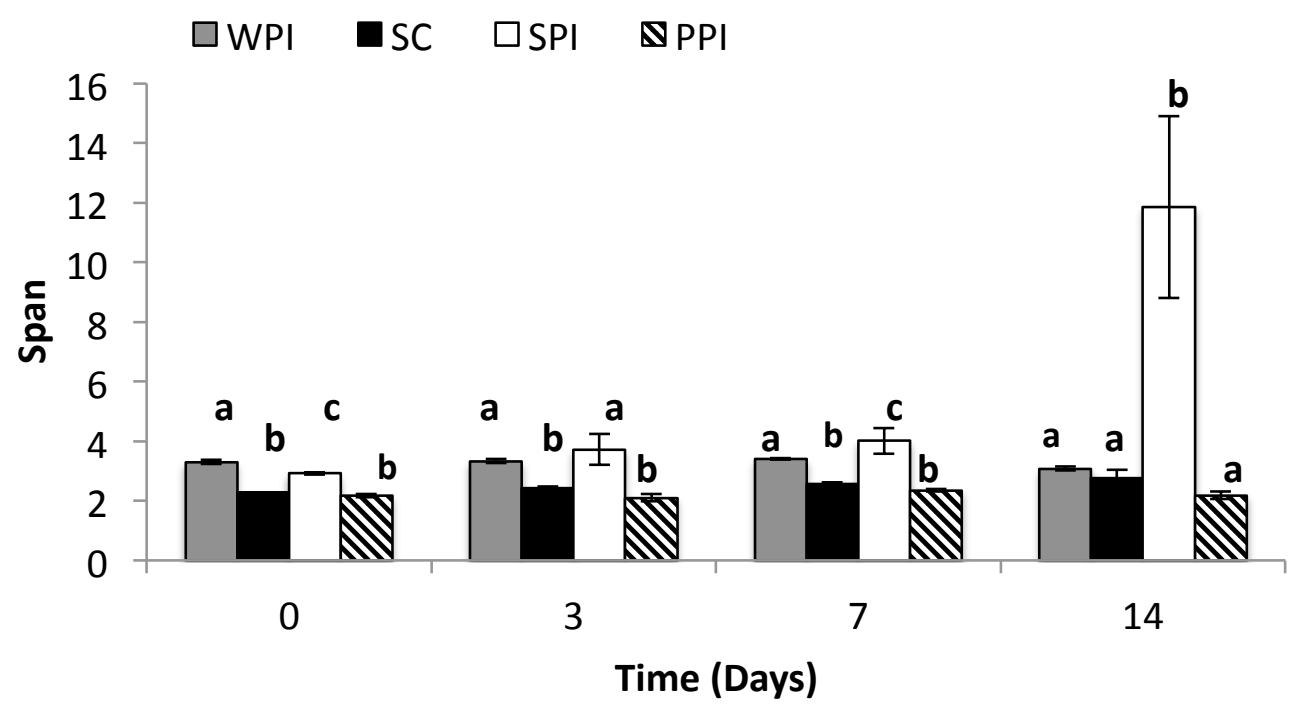

Figure A.2. Span of lycopene-loaded emulsions over time. Response values shown represent the mean + standard deviation $(n=3)$, with same letters denoting values that are not significantly different $(\alpha=0.05)$.

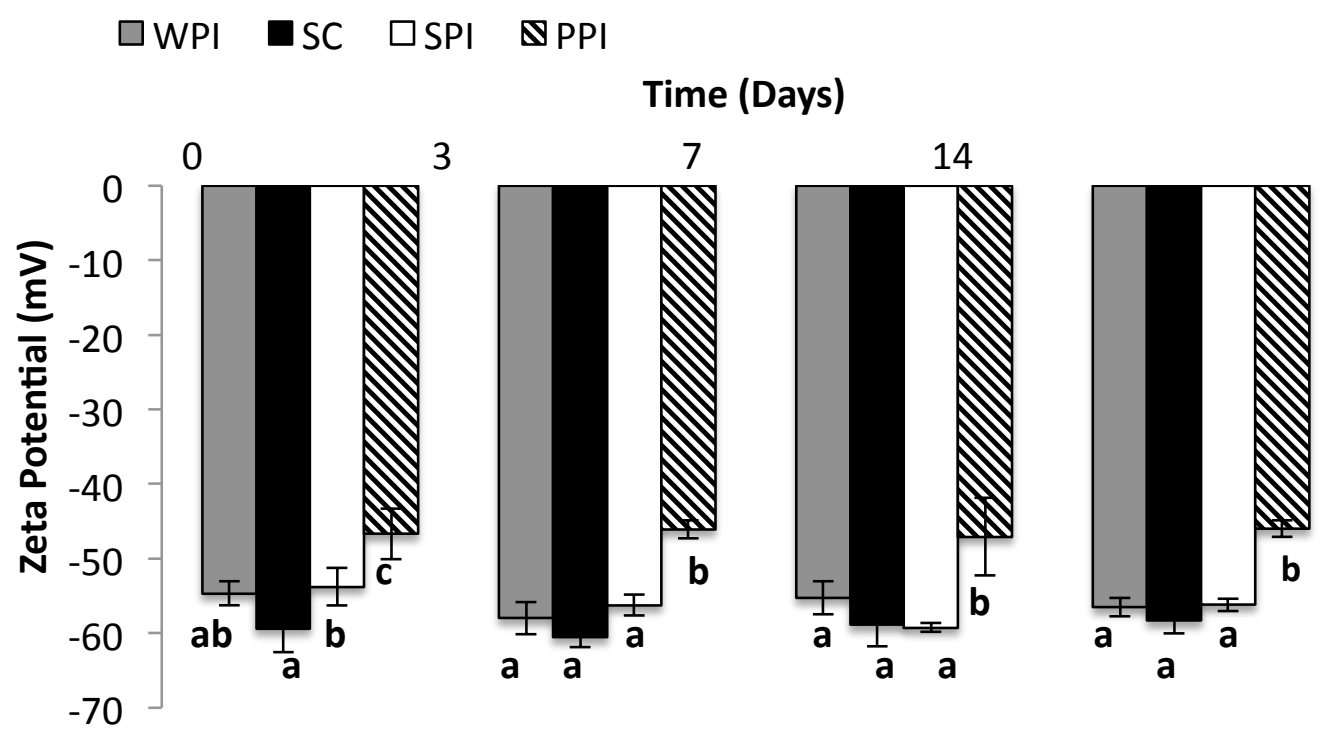

Figure A.3. Initial zeta potential of lycopene-loaded emulsions fabricated with proteins and protein blends. Response values shown represent the mean + standard deviation $(n=3)$, with same letters denoting values that are not significantly different $(\alpha=0.05)$. 


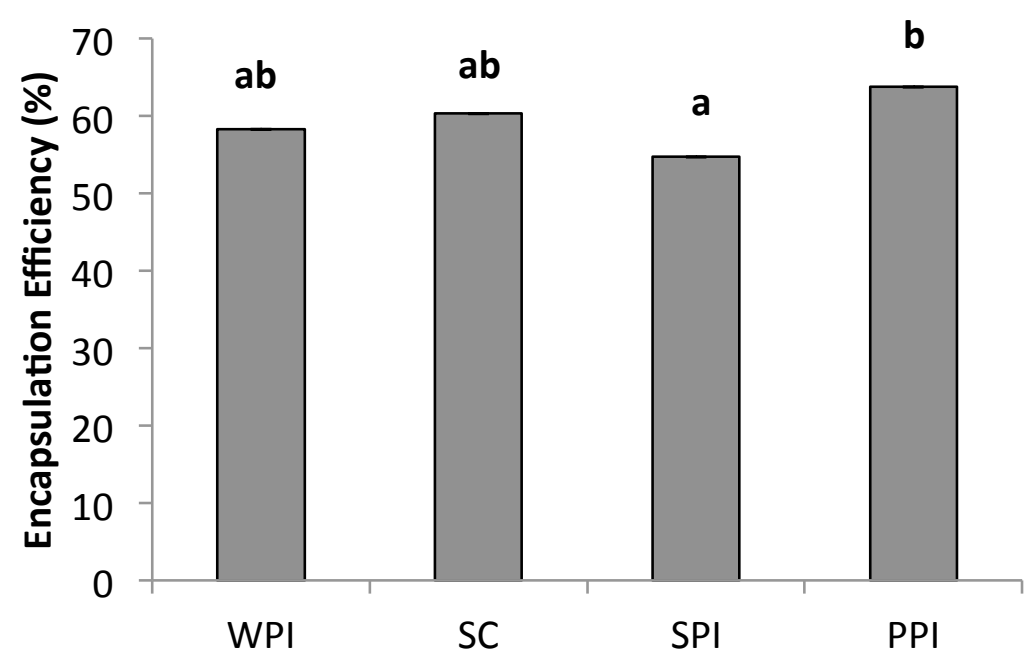

Figure A.4. Encapsulation efficiency of lycopene in protein stabilized emulsions at $\mathrm{t}=14$ days. Response values shown represent the mean + standard deviation $(n=3)$, with same letters denoting values that are not significantly different $(\alpha=0.05)$.

Table A.1. Physical properties of the different protein samples in phosphate buffer (10 mM, pH

\begin{tabular}{|c|c|c|c|}
\hline \multicolumn{4}{|c|}{$7.0)$} \\
\hline & Solubility (wt\%) ${ }^{a}$ & Particle size $(\mathrm{nm})^{\text {b }}$ & Zeta potential $(\mathrm{mV})^{\mathrm{b}}$ \\
\hline WPI & $\sim 100$ & $5.0 \pm 0.1$ & $-16.4 \pm 1.7$ \\
\hline SC & $\sim 100$ & $13.7 \pm 1.9$ & $-25.8 \pm 1.5$ \\
\hline SPI & $30.2 \pm 0.4$ & $112.2 \pm 33.4$ & $-23.2 \pm 1.3$ \\
\hline $\mathrm{PPI}^{*}$ & $25.1 \pm 2.4$ & $\begin{array}{c}\text { Main peak: } 37.3 \pm 7.0 \\
\text { Second peak: } 248.6 \pm 31.8\end{array}$ & $-22.9 \pm 1.3$ \\
\hline
\end{tabular}




\section{References}

Alting, A. C., Hamer, R. J., de Kruif, C. G., \& Visschers, R. W. (2000). Formation of Disulfide Bonds in Acid-Induced Gels of Preheated Whey Protein Isolate. Journal of Agricultural and Food Chemistry, 48(10), 5001-5007. http://doi.org/10.1021/jf000474h

Aoki, H., Taneyama, O., \& Inami, M. (1980). Emulsifyng properties of soy protein:

Characteristics of 7S and IIS proteins. Journal of Food Science, 45(3), 534-538. http://doi.org/10.1111/j.1365-2621.1980.tb04095.x

Ax, K., Mayer-Miebach, E., Link, B., Schuchmann, H., \& Schubert, H. (2003). Stability of lycopene in oil-in-water emulsions. Engineering in Life Sciences, 3(4), 199-201. http://doi.org/10.1002/elsc.200390028

Bengoechea, C., Cordobés, F., \& Guerrero, A. (2006). Rheology and microstructure of gluten and soya-based o/w emulsions. Rheologica Acta, 46(1), 13-21. http://doi.org/10.1007/s00397-006-0102-6

Benjamin, O., Silcock, P., Beauchamp, J., Buettner, A., \& Everett, D. W. (2014). Emulsifying Properties of Legume Proteins Compared to $\beta$-Lactoglobulin and Tween 20 and the Volatile Release from Oil-in-Water Emulsions. Journal of Food Science, 79(10), E2014-E2022. http://doi.org/10.1111/1750-3841.12593

Berton-Carabin, C. C., Ropers, M., \& Genot, C. (2014). Lipid Oxidation in Oil-in-Water Emulsions: Involvement of the Interfacial Layer. Comprehensive Reviews in Food Science and Food Safety, 13(5), 945-977.

Berton, C., Genot, C., \& Ropers, M.-H. (2011). Quantification of unadsorbed protein and surfactant emulsifiers in oil-in-water emulsions. Journal of Colloid and Interface Science, 354(2), 739-748. http://doi.org/http://dx.doi.org/10.1016/j.jcis.2010.11.055

Berton, C., Ropers, M.-H., Bertrand, D., Viau, M., \& Genot, C. (2012). Oxidative stability of oilin-water emulsions stabilised with protein or surfactant emulsifiers in various oxidation conditions. Food Chemistry, 131(4), 1360-1369. http://doi.org/10.1016/j.foodchem.2011.09.137

Berton, C., Ropers, M.-H., Viau, M., \& Genot, C. (2011). Contribution of the Interfacial Layer to the Protection of Emulsified Lipids against Oxidation. Journal of Agricultural and Food 


\section{Food Structure}

Volume 12, 2017, Pages 34-42

Chemistry, 59(9), 5052-5061. http://doi.org/10.1021/jf200086n

Bos, M. A., \& van Vliet, T. (2001). Interfacial rheological properties of adsorbed protein layers and surfactants: a review. Advances in Colloid and Interface Science, 91(3), 437-471. http://doi.org/10.1016/S0001-8686(00)00077-4

Boye, J. I., Aksay, S., Roufik, S., Ribéreau, S., Mondor, M., Farnworth, E., \& Rajamohamed, S. H. (2010). Comparison of the functional properties of pea, chickpea and lentil protein concentrates processed using ultrafiltration and isoelectric precipitation techniques. Food Research International, 43(2), 537-546. http://doi.org/10.1016/j.foodres.2009.07.021

Britton, G., Liaaen-Jensen, S., \& Pfander, H. (2004). Carotenoid Handbook Info.pdf. Basel, Switzerland: Birkhauser Verlag.

Chang, C., Tu, S., Ghosh, S., \& Nickerson, M. T. (2015). Effect of pH on the inter-relationships between the physicochemical, interfacial and emulsifying properties for pea, soy, lentil and canola protein isolates. Food Research International, 77(3), 360-367. http://doi.org/10.1016/j.foodres.2015.08.012

Chihi, M.-L., Mession, J., Sok, N., \& Saurel, R. (2016). Heat-Induced Soluble Protein Aggregates from Mixed Pea Globulins and $\beta$-Lactoglobulin. Journal of Agricultural and Food Chemistry, 64(13), 2780-2791. http://doi.org/10.1021/acs.jafc.6b00087

Chove, B. E., Grandison, A. S., \& Lewis, M. J. (2001). Emulsifying properties of soy protein isolate fractions obtained by isoelectric precipitation. Journal of the Science of Food and Agriculture, 81(8), 759-763. http://doi.org/10.1002/jsfa.877

Chronakis, I. S. (1996). Network formation and viscoelastic properties of commercial soy protein dispersions: effect of heat treatment, $\mathrm{pH}$ and calcium ions. Food Research International, 29(2), 123-134. http://doi.org/10.1016/0963-9969(96)00018-X

Clausen, M. R., Skibsted, L. H., \& Stagsted, J. (2009). Characterization of Major Radical Scavenger Species in Bovine Milk through Size Exclusion Chromatography and Functional Assays. Journal of Agricultural and Food Chemistry, 57(7), 2912-2919. http://doi.org/10.1021/jf803449t

Cornacchia, L., \& Roos, Y. H. (2011). Stability of $\beta$-Carotene in Protein-Stabilized Oil-in-Water Delivery Systems. Journal of Agricultural and Food Chemistry, 59(13), 7013-7020. http://doi.org/10.1021/jf200841k

de Boer, J., Helms, M., \& Aiking, H. (2006). Protein consumption and sustainability: Diet 
diversity in EU-15. Ecological Economics, 59(3), 267-274.

http://doi.org/10.1016/j.ecolecon.2005.10.011

Di Mascio, P., Kaiser, S., \& Sies, H. (1989). Lycopene as the most efficient biological carotenoid singlet oxygen quencher. Archives of Biochemistry and Biophysics, 274(2), 532-538. http://doi.org/http://dx.doi.org/10.1016/0003-9861(89)90467-0

Dickinson, E. (1992). Faraday research article. Structure and composition of adsorbed protein layers and the relationship to emulsion stability. Journal of the Chemical Society, Faraday Transactions, 88(20), 2973. http://doi.org/10.1039/ft9928802973

Dickinson, E. (2001). Milk protein interfacial layers and the relationship to emulsion stability and rheology. Colloids and Surfaces B: Biointerfaces, 20(3), 197-210. http://doi.org/10.1016/S0927-7765(00)00204-6

Dickinson, E. (2010). Flocculation of protein-stabilized oil-in-water emulsions. Colloids and Surfaces. B, Biointerfaces, 81(1), 130-40. http://doi.org/10.1016/j.colsurfb.2010.06.033

Dickinson, E. (2011). Mixed biopolymers at interfaces: Competitive adsorption and multilayer structures. Food Hydrocolloids, 25(8), 1966-1983. http://doi.org/10.1016/j.foodhyd.2010.12.001

Dickinson, E. (2013). Stabilising emulsion-based colloidal structures with mixed food ingredients. Journal of the Science of Food and Agriculture, 93(4), 710-21. http://doi.org/10.1002/jsfa.6013

Dickinson, E., Owusu, R. K., Tan, S., \& Williams, A. (1993). Oil-soluble Surfactants Have Little Effect on Competitive Adsorption of $\beta$-Lactalbumin and $\beta$-Lactoglobulin in Emulsions. Journal of Food Science, 58(2), 295-298. http://doi.org/10.1111/j.13652621.1993.tb04259.x

Erb K.H., Lauk C., Kastner T., Mayer A., Theurl M.C., Haberl H. (2016). Exploring the biophysical option space for feeding the world without deforestation. Nature Communications, In press.

Erni, P., Windhab, E. J., \& Fischer, P. (2011). Emulsion drops with complex interfaces: Globular versus flexible proteins. Macromolecular Materials and Engineering, 296(3-4), 249-262. http://doi.org/10.1002/mame.201000290

Faraji, H., Mcclements, D. J., \& Decker, E. A. (2004). Role of Continuous Phase Protein on the Oxidative Stability of Fish Oil-in-Water Emulsions. Journal of Agricultural and Food 


\section{Food Structure}

Volume 12, 2017, Pages 34-42

Chemistry, 52(14), 4558-4564. http://doi.org/10.1021/jf035346i

Fernandez-Avila, C., Arranz, E., Guri, A., Trujillo, A. J., \& Corredig, M. (2016). Vegetable protein isolate-stabilized emulsions for enhanced delivery of conjugated linoleic acid in Caco-2 cells. Food Hydrocolloids, 55, 144-154.

http://doi.org/10.1016/j.foodhyd.2015.10.015

Freer, E.M., Yim, K.S., Fuller, G.G., \& Radke, C.J. (2004). Interfacial rheology of globular and flexible proteins at the hexadecane/water interface: comparison of shear and dilatation deformation. J. Phys. Chem., 108(12), 3835-3844. http://doi.org/ 10.1021/jp037236k

Georgieva, D., Schmitt, V. E., Leal-Calderon, F., \& Langevin, D. (2009). On the Possible Role of Surface Elasticity in Emulsion Stability. Langmuir, 25(10), 5565-5573. http://doi.org/10.1021/la804240e

Han, H., \& Baik, B.K. (2008). Antioxidant activity and phenolic content of lentils (Lens culinaris), chickpeas (Cicer arientinum L.), peas (Pisum sativum L.) and soybeans (Glycine max) and their quantitative changes during processing. International Journal of Food Science \& Technology, 43(11), 1971-1978. http://doi.org/10.1111/j.13652621.2008.01800.x

Ho, K. K. H. Y., Ferruzzi, M. G., Liceaga, A. M., \& San Martín-González, M. F. (2015). Microwave-assisted extraction of lycopene in tomato peels: Effect of extraction conditions on all-trans and cis-isomer yields. LWT - Food Science and Technology, 62(1), 160-168. http://doi.org/10.1016/j.lwt.2014.12.061

Hu, M., McClements, D. J., \& Decker, E. A. (2003). Lipid oxidation in corn oil-in-water emulsions stabilized by casein, whey protein isolate, and soy protein isolate. Journal of Agricultural and Food Chemistry, 51(6), 1696-1700. http://doi.org/10.1021/jf020952j

Kean, E. G., Hamaker, B. R., \& Ferruzzi, M. G. (2008). Carotenoid Bioaccessibility from Whole Grain and Degermed Maize Meal Products. Journal of Agricultural and Food Chemistry, 56(21), 9918-9926. http://doi.org/10.1021/jf8018613

Lam, R. S. H., \& Nickerson, M. T. (2013). Food proteins: a review on their emulsifying properties using a structure-function approach. Food Chemistry, 141(2), 975-84. http://doi.org/10.1016/j.foodchem.2013.04.038

Let, M. B., Jacobsen, C., Sørensen, A.D. M., \& Meyer, A. S. (2007). Homogenization Conditions Affect the Oxidative Stability of Fish Oil Enriched Milk Emulsions: Lipid 


\section{Food Structure}

Volume 12, 2017, Pages 34-42

Oxidation. Journal of Agricultural and Food Chemistry, 55(5), 1773-1780.

http://doi.org/10.1021/jf062391s

Lethuaut, L., Métro, F., \& Genot, C. (2002). Effect of droplet size on lipid oxidation rates of oilin-water emulsions stabilized by protein. Journal of the American Oil Chemists' Society, 79(5), 425-430. http://doi.org/10.1007/s11746-002-0500-z

Liu, S., Elmer, C., Low, N. H., \& Nickerson, M. T. (2010). Effect of pH on the functional behaviour of pea protein isolate-gum Arabic complexes. Food Research International, 43(2), 489-495. http://doi.org/10.1016/j.foodres.2009.07.022

Maldonado-Valderrama, J., Fainerman, V. B., Gálvez-Ruiz, M. J., Martín-Rodriguez, A., Cabrerizo-Vílchez, M. A., \& Miller, R. (2005). Dilatational Rheology of $\beta$-Casein Adsorbed Layers at Liquid-Fluid Interfaces. Journal of Physical Chemistry, 109(37), 17608-17616. http://doi.org/10.1021/jp050927r

Mao, Li., Xu, D., Yang, J., Yuan, F., Gao, Y., \& Zhao, J. (2009). Effects of Small and Large Molecule Emulsifiers on the Characteristics of $\beta$-Carotene Nanoemulsions Prepared by High Pressure Homogenization. Food Technology Biotechnology, 47(3), 336-342.

Mao, Li., Yang, J., Yuan, F., \& Gao, Y. (2010). Effects of homogenization models and emulsifiers on the physicochemical properties of $\beta$-carotene nanoemulsions. Journal of Dispersion Science and Technology, 31(7). http://doi.org/10.1080/01932690903224482

McClements, D. J., Monahan, F. J., \& Kinsella, J. E. (1993). Disulfide Bond Formation Affects Stability of Whey Protein Isolate Emulsions. Journal of Food Science, 58(5), 1036-1039. http://doi.org/10.1111/j.1365-2621.1993.tb06106.x

Min Hu, D. Julian McClements, A., \& Decker, E. A. (2003). Impact of Whey Protein Emulsifiers on the Oxidative Stability of Salmon Oil-in-Water Emulsions. Journal of Agricultural and Food Chemistry, 51(5), 1235-1439.

Murray, B. S. (2011). Rheological properties of protein films. Current Opinion in Colloid \& Interface Science, 16(1), 27-35. http://doi.org/10.1016/j.cocis.2010.06.005

Nakai, S., \& Li-Chan, E. (1988). Hydrophobic interactions in food systems. CRC Press.

O’Kane, F. E., Vereijken, J. M., Happe, R. P., Gruppen, H., \& J S Van Boekel, M. A. (2004). Heat-Induced Gelation of Pea Legumin: Comparison with Soybean Glycinin. Journal of Agricultural and Food Chemistry, 52(16), 5071-5078. http://doi.org/10.1021/jf035215h

Osborn, H. T., \& Akoh, C. C. (2004). Effect of emulsifier type, droplet size, and oil 
concentration on lipid oxidation in structured lipid-based oil-in-water emulsions. Food Chemistry, 84(3), 451-456. http://doi.org/10.1016/S0308-8146(03)00270-X

Pelgrom, P. J. M., Boom, R. M., \& Schutyser, M. A. I. (2015). Functional analysis of mildly refined fractions from yellow pea. Food Hydrocolloids, 44, 12-22. http://dx.doi.org.ezproxy.lib.purdue.edu/10.1016/j.foodhyd.2014.09.001

Pelgrom, P. J. M., Berghout, J. A. M., Van Der Goot, J., Boom, R. M., \& Schutyser, M. A. I. (2014). Preparation of functional lupine protein fractions by dry separation. LWT - Food Science and Technology, 59, 680-688. http://doi.org/10.1016/j.lwt.2014.06.007

Phoon, P. Y., Paul, L. N., Burgner, J. W., Fernanda San Martin-Gonzalez, M., \& Narsimhan, G. (2014). Effect of Cross-Linking of Interfacial Sodium Caseinate by Natural Processing on the Oxidative Stability of Oil-in-Water (O/W) Emulsions. Journal of Agricultural and Food Chemistry, 62(13), 2822-2829. http://doi.org/10.1021/jf403285z

Phoon, P. Y., San Martin-Gonzalez, M. F., \& Narsimhan, G. (2014). Effect of hydrolysis of soy $\beta$-conglycinin on the oxidative stability of $\mathrm{O} / \mathrm{W}$ emulsions. Food Hydrocolloids, 35, 429443. http://doi.org/10.1016/j.foodhyd.2013.06.024

Rao, A. V, Waseem, Z., \& Agarwal, S. (1998). Lycopene content of tomatoes and tomato products and their contribution to dietary lycopene. Food Research International, 31(10), 737-741. http://doi.org/http://dx.doi.org/10.1016/S0963-9969(99)00053-8

Ribeiro, H. S., Guerrero, J. M. M., Briviba, K., Rechkemmer, G., Schuchmann, H. P., \& Schubert, H. (2006). Cellular Uptake of Carotenoid-Loaded Oil-in-Water Emulsions in Colon Carcinoma Cells in Vitro. Journal of Agricultural and Food Chemistry, 54(25), 9366-9369. http://doi.org/10.1021/jf062409z

Shi, W., \& Dumont, M.J. (2014). Review: bio-based films from zein, keratin, pea, and rapeseed protein feedstocks. Journal of Material Science, 49(5), 1915-1930. http://doi.org/10.1007/s10853-013-7933-1

Song, F., Tang, D.L., Wang, X.L., \& Wang, Y.-Z. (2011). Biodegradable Soy Protein IsolateBased Materials: A Review. Biomacromolecules, 12(10), 3369-3380. http://doi.org/10.1021/bm200904x

Sugiarto, M., Ye, A., Taylor, M. W., Singh, H., \& Singh, H. (2010). Milk protein-iron complexes: Inhibition of lipid oxidation in an emulsion. Dairy Science \& Technology, 90(1), 87-98. http://doi.org/10.1051/dst/2009053 
Tapal, A., \& Tiku, P. K. (2012). Complexation of curcumin with soy protein isolate and its implications on solubility and stability of curcumin. Food Chemistry, 130, 960-965. http://doi.org/10.1016/j.foodchem.2011.08.025

Thermoscientific. (2015). Pierce BCA Protein Assay Kit. Retrieved June 14, 2016, from https://tools.thermofisher.com/content/sfs/manuals/MAN0011430_Pierce_BCA_Protein_As y_UG.pdf

Toikkanen, O., Lä Hteenmä Ki, M., Moisio, T., Forssell, P., Partanen, R., \& Murtomä, L. (2014). Study of Oxygen Transfer across Milk Proteins at an Air-Water Interface with Scanning Electrochemical Microscopy. Journal of Agricultural and Food Chemistry, 62(10), 22842288. http://doi.org/10.1021/jf5008715

Tong, L. M., Sasaki, S., Mcclements, D. J., \& Decker, E. A. (2000). Mechanisms of the Antioxidant Activity of a High Molecular Weight Fraction of Whey. Journal of Agricultural and Food Chemistry, 48(5), 1473-1478. http://doi.org/10.1021/jf991342v

VandeHaar M.J., St-Pierre N. (2006). Major advances in nutrition: relevance to the sustainability of the dairy industry. Journal of Dairy Science, 89(4),1280-1291.

Wilde, P.J. (2000). Interfaces: their role in foam and emulsion behaviour. Current Opinion in Colloid \& Interface Science, 5(3), 176-181. http://doi.org/10.1016/S1359-0294(00)00056$\mathrm{X}$ 